\title{
Molecular Characterization of Potato virus V Genomes from Europe Indicates Limited Spatiotemporal Strain Differentiation
}

\author{
Igor Oruetxebarria, Tuija Kekarainen, Carl Spetz, and Jari P. T. Valkonen
}

Department of Plant Biology, Genetic Centre, SLU, P.O. Box 7080, S-750 07 Uppsala, Sweden.

Accepted for publication 11 January 2000.

\begin{abstract}
Oruetxebarria, I., Kekarainen, T., Spetz, C., and Valkonen, J. P. T. 2000. Molecular characterization of Potato virus $V$ genomes from Europe indicates limited spatiotemporal strain differentiation. Phytopathology 90:437-444.

Because there were no previous reports on the molecular characterization of Potato virus V (PVV, genus Potyvirus, family Potyviridae), the complete genomic sequence of PVV isolate Dv42 was determined. The length of the single-stranded messenger-polarity RNA genome was $9,851 \mathrm{nt}$ (nucleotides), followed by a poly(A) tail. The genome contained a $5^{\prime}$-terminal nontranslated region (5'-NTR; 204 nt), a single open reading frame (nucleotides 205-9406; 3,067 amino acids), and a 3'-NTR that was unusually long (446 nt) compared with that of Potato virus Y (PVY; 331-nt 3'-NTR), Potato virus A (PVA; 207-nt 3'-NTR), and other potyviruses that naturally infect Solanaceae species. Phylogenetic analysis with the cylindrical inclusion protein-encoding and coat protein (CP)encoding regions indicated that PVV Dv42 was most closely related to

Pepper mottle virus and PVY, respectively. Seven PVV isolates (including Dv42) collected from cultivated potatoes in the Netherlands, the United Kingdom, and Norway from 1964 to 1997 were uniform in serological properties and symptomatology in indicator hosts that could distinguish strains of PVY and PVA. The nucleotide sequences of the 5'NTR, P1, CP, and 3'-NTR regions of the PVV isolates were determined and were 94.6 to $99.5,96.3$ to $98.8,96.4$ to 98.7 , and 96.3 to $99.6 \%$ identical, respectively. The amino acid similarities for the P1 and CP were 95.8 to 98.6 and 96.0 to $97.8 \%$, respectively. Phylogenetic analysis of the CP sequences of PVV revealed no significant grouping, in contrast to PVY and PVA, which were grouped largely according to the previously recognized strains based on host responses. However, the relatively few differences in the P1 sequences of PVV were correlated with the different countries of origin. Hence, the PVV isolates infecting potatoes in Europe seem to vary little genetically and may belong to a single strain.
\end{abstract}

Potyviruses (genus Potyvirus, family Potyviridae) have a singlestranded messenger-polarity RNA genome and belong to the picornavirus-like supergroup $(40,52)$. They form the largest and most economically the most important group of plant viruses (52). Potyviruses are nonpersistently transmitted by aphids and, therefore, are difficult to control unless resistant cultivars are available (52).

Three potyviruses are economically important in cultivated potato (Solanum tuberosum L., family Solanaceae). Potato virus $Y$ (PVY) $(7,15,46,62)$ occurs in potatoes worldwide and can cause high yield losses (up to 80\%) (25). Isolates from potato are classified into three main strains: the common strain $\left(\mathrm{PVY}^{\mathrm{O}}\right)$, the tobacco veinal necrosis strain $\left(\mathrm{PVY}^{\mathrm{N}}\right)$, and the stipple streak strain $\left(\mathrm{PVY}^{\mathrm{C}}\right)$. $\mathrm{PVY}^{\mathrm{O}}$ and $\mathrm{PVY}^{\mathrm{C}}$ can be distinguished by the strain-specific elicitation of genes $N y$ and $N c$, respectively, for hypersensitive resistance (HR) in potato, and $\mathrm{PVY}^{\mathrm{N}}$ is distinguished by the vein necrosis it induces in tobacco (Nicotiana tabacum L.) (15). A subgroup of $\mathrm{PVY}^{\mathrm{N}}$ isolates causes necrotic symptoms on the tubers of some potato cultivars and has been designated PVY ${ }^{\text {NTN }}$ $(37,61)$. PVY occurs also in other crops, including pepper (Capsicum spp.) and tobacco, and strain differentiation according to host species has been documented $(23,38)$. The grouping of PVY isolates into strains based on biological criteria is largely according to the grouping of isolates based on phylogenetic analysis of the coat protein $(\mathrm{CP})$ gene sequences $(7,61,62)$.

Potato virus $A$ (PVA) $(5,33,43,44)$ also occurs in potatoes worldwide and can reduce yields by $40 \%$ (25). Isolates of PVA from potato are grouped into three strains based on differential interactions with potato cv. King Edward (44,59). PVA is uncommon in other crops. However, one strain (TamMV) naturally infects tam-

Corresponding author: J. Valkonen; E-mail address: jari.valkonen@ vbiol.slu.se

Publication no. P-2000-0224-01R

(c) 2000 The American Phytopathological Society arillo (Solanum betacea Bohs) (9) and is distinguishable from potato isolates based on its genomic sequence and host responses (33, 44). In addition, a distinct strain of PVA has been described that consists of isolates that were originally obtained from potato but that have been experimentally maintained in Nicotiana spp. for a long time; they no longer infect potato cultivars systemically and are not transmitted by aphids $(2,33,44)$. The potato, tamarillo, and tobacco strains of PVA can be distinguished by phylogenetic analysis of the CP and P1 gene sequences $(33,44)$.

The third potyvirus that infects cultivated potatoes was described more recently and designated Potato virus $V$ (PVV) $(21,30)$. It is known to occur only in a limited number of potato cultivars in the Andean Region of South America and western Europe and usually causes only mild symptoms $(21,27,28,30,32)$. No other natural hosts are known, and no strains have been described. PVV is distinguishable from PVY and PVA strains because it does not activate the genes for hypersensitive resistance (HR) to PVY and PVA $(21,29,57)$, it shows only a distant serological relationship to PVY and PVA $(21,28)$, and it does not cross-protect against PVY and PVA (21). However, a few PVV isolates from Europe (PVY-C G1 [49] and PVY-C AB [10]) originally were considered deviant isolates of $\mathrm{PVY}^{\mathrm{C}}$ because they caused necrotic symptoms in some cultivars carrying the $N c$ gene. It was later found that these cultivars also contain the $N v$ gene that specifically recognizes PVV, resulting in HR and necrotic symptoms $(21,29)$.

The potyviruses that naturally infect solanaceous species show higher relatedness based on host range, serology, and sequence data than is found among other potyviruses $(6,19,52)$. Little molecular data on PVV are available to establish it as a distinct potyvirus. An unpublished $\mathrm{CP}$ gene sequence (EMBL Accession no. $\mathrm{X} 61279$ ) from one PVV isolate has been compared with the $\mathrm{CP}$ sequences of other potyviruses, and this sequence indicates that PVV is more closely related to Pepper mottle virus (PepMoV) 
than to PVY and PVA (6). Little information is available about the serological relatedness of PVV and PepMoV, whereas both PVV and PepMoV are distantly related serologically to PVY $(21,42)$. Although the CP sequence of a single PVV isolate suggests that PVV is a distinct potyvirus $(6,17)$, mapping of its complete genomic sequence is required to establish unequivocally its relationship to other potyviruses.

The characteristics used for delineation of virus species also have been used for identification of virus strains (39). It has been shown that the isolates of $\mathrm{PVY}^{\mathrm{C}}$ consist of two genetic strains distinguished by differences in their CP sequences, even though they are indistinguishable based on host responses or serology (7). These data show the difficulty in recognizing strains of closely related potyvirus species that have narrow and partially overlapping host ranges and are serologically related and emphasize the usefulness of molecular data in augmenting other characterizations.

In this study, the entire nucleotide sequence and genomic organization of PVV were determined and compared with other potyviruses. A phylogenetic analysis clarifying the taxonomic relationship of PVV among the group of potyviruses infecting Solanaceae was done with the coat protein (CP) and cylindrical inclusion (CI) protein sequences, as recommended by previous researchers (36, 52). The CI protein sequence is particularly appropriate for establishing the relationships between potyvirus species, because this relatively large genetic region is the least variable between different strains of a species $(33,36)$. Genetic variability of PVV in Europe was studied with seven PVV isolates obtained from potatoes in three countries during the past 35 years. The sequences of the 5'-terminal P1 gene and 3 '-terminal CP gene (the most variable regions in potyviruses [1,33]) were determined and compared by phylogenetic analysis, including the previously mentioned, unpublished CP sequence of one additional PVV isolate. The sequence data together with the uniform symptoms observed in indicator hosts indicated that the isolates of PVV in Europe vary little and probably form a single strain.

TABLE 1. Isolates of Potato virus $V$ used in the study

\begin{tabular}{lllcl}
\hline Isolate & \multicolumn{1}{c}{ Origin } & $\begin{array}{c}\text { Source } \\
\text { (potato cultivar) }\end{array}$ & $\begin{array}{c}\text { Year } \\
\text { isolated }\end{array}$ & \multicolumn{1}{c}{ Supplier ${ }^{\mathrm{a}}$} \\
\hline 508 & Netherlands & Vroege Paarse & 1964 & van den Heuvel \\
506 & Netherlands & Luijker Tonge & 1965 & van den Heuvel \\
502 & Netherlands & Gladblaadje & 1976 & van den Heuvel \\
Ringeriks & Norway & Ringerikspotet & 1990 & Munthe \\
DV42 & U.K. (Scotland) & Estima & 1994 & Browning \\
M95 & U.K. (England) & Unknown & 1995 & Clover \\
M97 & U.K. (England) & Unknown & 1997 & Clover \\
\hline
\end{tabular}

a J. F. J. M. van den Heuvel, IPO, Wageningen, Netherlands; T. Munthe, Planteforsk, Ås, Norway; I. A. Browning, Scottish Agricultural Science Agency, Edinburgh; G. Clover, MAFF, York, England.

\section{MATERIALS AND METHODS}

Virus isolates. A total of seven isolates of PVV were obtained from the Netherlands, the United Kingdom, and Norway (Table 1); all had been isolated from field-grown potatoes from 1964 to 1997 and maintained in potato cultivars. All isolates were mechanically inoculated to potato clone 'A6' $(S$. demissum $\times$ S. tuberosum 'Aquila'), which is susceptible to PVV (21) but has a HR reaction to PVA and PVY $(14,44,58,59)$ (experimental conditions are discussed below). Subsequently, the viruses were transmitted mechanically from systemically infected leaves of A6 plants to tobacco plants (cv. Samsun nn). Systemically infected tobacco leaves were tested for PVV, PVY, PVA, Potato virus M, Potato virus S, and Potato virus $X$ by double-antibody sandwich enzyme-linked immunosorbent assay (DAS-ELISA) 16 days after inoculation and used for purification of PVV $(8,21)$.

Isolates PVY ${ }^{\mathrm{O}}-\mathrm{UK}, \mathrm{PVY}^{\mathrm{N}}$-RUS, PVA-B11, PVA-U, PVA-TamMV, and the PepMoV isolate (provided by R. Grube and M. Kyle, Cornell University, Ithaca, NY) have been described previously $(33,44$, $55,58)$. Isolates were propagated by mechanical inoculation in tobacco cv. Samsun nn, except for PVYN ${ }^{\mathrm{N}}$-RUS, which was obtained from sprouts of an infected tuber of potato cv. Valtti.

Plants and inoculation. Healthy plants of A6 and potato cv. Pentland Crown were transferred from tissue culture to soil and propagated by taking shoot cuttings. Pepper (C. annuum cv. RNaky) (58) and tobacco plants were grown from seeds (pepper seeds were provided by R. Grube and M. Kyle). All plants were grown, and experiments were carried out in a growth chamber (Weiss Umweltstechnik, Reiskirchen, Germany; $8.8 \mathrm{~m}^{2}$, photoperiod $18 \mathrm{~h}$, light intensity $250 \mu \mathrm{E} \mathrm{s}^{-1} \mathrm{~m}^{-2}$, temperatures 19 and $17^{\circ} \mathrm{C}$ [day and night], relative humidity $40 \%$ ) under highly constant conditions.

Viruses were mechanically inoculated by grinding infected leaves in sterile distilled water $(1 \mathrm{~g} / 5 \mathrm{ml})$ and rubbing sap on one Carborundum-dusted lower leaf of 3-week-old cuttings of A6 and Pentland Crown or 4-week-old seedlings of tobacco. Two cotyledons of pepper plants were inoculated when the first two true leaves were $\approx 5 \mathrm{~cm}$ long. Pentland Crown plants were side-graft inoculated (56) with the PVV isolates, using apical shoots from PVVinfected A6 plants. Three plants of each genotype and species were inoculated with the seven PVV isolates, and all experiments were carried out two or three times. Symptoms were observed until 21 and 28 days after mechanical and graft inoculation, respectively. The uppermost fully expanded leaf of each plant was tested for PVV infection by DAS-ELISA. Inoculated cotyledons of pepper plants also were tested.

Aphid transmissibility of PVV was tested with a culture of $M y$ zus persicae Sulzer provided by B.-L. Lennefors (Novartis Seeds, Landskrona, Sweden). Aphids were reared on oilseed rape (Brassica napus L.) in the laboratory at 18 to $23^{\circ} \mathrm{C}$. Aphids were starved for $2 \mathrm{~h}$, placed on a detached PVV-infected tobacco leaf for $60 \mathrm{~s}$

TABLE 2. Synthetic deoxyoligonucleotides used for cloning the Potato virus $V$ isolate Dv42 genome

\begin{tabular}{|c|c|c|}
\hline No. & Oligonucleotide sequence & Position $^{\mathrm{a}}$ \\
\hline 1 & 5'-GTTTCAATTGGTGCAGCTGTG & $7599-7619(-)(\text { and } 6328-6348[+])^{\mathrm{b}}$ \\
\hline 2 & 5'-CAAGGAGCCAAACCCAATGCCATG & $6391-6414(-)$ \\
\hline 3 & 5'-GTGTCCGCCACACCACCAGG & $4276-4295(+)$ \\
\hline 4 & 5'-CGAGCCATGTTGGATAACATCTG & $4397-4419(-)(\text { and } 2116-2138[+])^{\mathrm{b}}$ \\
\hline 5 & 5'-GCCACTTCCCAAGTTTGGGGA & $2186-2206(-)$ \\
\hline 6 & 5'-GTCTCGCACCTTCTTAGTGAAATCTTTTGC & $2149-2178(-)$ \\
\hline 7 & 5'-TTCCAACAGTGCCTCGCTGTCAA & $1036-1057(-)$ \\
\hline 8 & 5'-GCTGCAAAGAGAAAATTGAAGCAA & $7559-7582(+)$ \\
\hline 9 & 5'-GGCCTCATTTCGGCCGGAGTTGCGGGGG & $954-980(+)$ \\
\hline 10 & 5'-TTTTTTTTTтTTTTTTTT & $9855-9872(-)$ \\
\hline 11 & 5'-AGAATCGTGTCCATCTTACAATGG & $8272-8285(+)$ \\
\hline 12 & 5'-AATTGCCAAGGCAAAGT & $61-77(-)$ \\
\hline 13 & 5'-AAAATTAAAACAATACATAACAGAAACAAACGAAAGCA & $1-38(+)$ \\
\hline
\end{tabular}

a Primer orientation: (+), sense; (-), antisense.

b These oligonucleotides recognize an additional, incompletely matching binding site in the (+) strand. 
for virus acquisition, and caged in batches of five aphids on leaves of healthy tobacco seedlings (one batch per plant). During the next morning, the aphids were killed with an aphicide. Tobacco plants were grown for 3 weeks, as described above, and tested for PVV by DAS-ELISA.

Virus detection. Virus detection by DAS-ELISA was carried out using previously described reagents and procedures (44). Monoclonal antibody (MAb) 53/8 to PVV and MAbs 58/0 and 58/6 to PVA, prepared by the Scottish Agricultural Science Agency (8), were obtained from Adgen (Ayr, Scotland). Polyclonal antibodies (PAb) to PVV (obtained from Bioreba, Carroboro, NC) and other viruses (obtained from Boehringer $\mathrm{GmbH}$, Mannheim, Germany) were used for DAS-ELISA (44), except those for PepMoV, which were supplied, accompanied with the protocol for indirect ELISA for PepMoV detection, by R. Grube and M. Kyle. The anti-rabbit PAbs conjugated with alkaline phosphatase used for indirect ELISA were obtained from Sigma Chemical Co. (St. Louis). $p$-Nitrophenyl phosphate was used as a substrate. Absorbance values were recorded at $405 \mathrm{~nm}$ with a Benchmark microtiter plate reader, using Microplate Manager software (Bio-Rad Laboratories, Hercules, CA).

Viral RNA purification, cDNA synthesis, cloning, and sequencing. RNA was isolated from $100 \mu \mathrm{g}$ of virions by disruption in $200 \mu$ of a highly denaturing lysis buffer (1\% sodium dodecyl sulfate, $0.3 \mathrm{M}$ Tris-HCl, $20 \mathrm{mM}$ EDTA, $\mathrm{pH} 8.0$ ) for $30 \mathrm{~min}$ at room temperature followed by cleaning and concentration steps, using RNeasy total RNA kit columns (Qiagen, Hilden, Germany) according to the manufacturer's instructions. The first strand of cDNA was synthesized by the Superscript II reverse transcriptase system (Gibco BRL Life Technologies, Gaithersburg, MD) primed with random hexamers $(\mathrm{dN})_{6}$ (Promega, Southampton, England).

The complete genomic sequence was determined from the PVV isolate Dv42, because it is the best characterized of the available European isolates $(8,55)$. The numbering of nucleotides (nt) and amino acids (aa) in the PVV genome are for PVV Dv42.

The design of synthetic oligonucleotides (Table 2) was based on the PVV CP gene nucleotide sequence (X61279) available from the EMBL database or according to the conserved genomic regions between different potyviruses (52) (Table 3) and used for cloning by polymerase chain reaction (PCR). Five overlapping PCR products spanning a total of 8,780 bp of the PVV Dv42 genome were amplified and cloned into the TA vector pCR2.1 (Invitrogen, Groningen, the Netherlands). All PCR reactions were performed with the Expand High Fidelity PCR system (Boehringer). Sequencing of cloned fragments was performed using a primer-walking strategy. Both strands of at least two independently amplified and cloned PCR products were sequenced with the Thermo Sequenase dye terminator cycle sequencing kit (Amersham, Little Chalfont, England). Sequencing reactions were analyzed with an automated ABI Prism XL377A DNA sequencer (Perkin-Elmer Cetus, Norwalk, CT).

The region of the PVV Dv42 genome containing the 5 'terminal nontranslated region ( $5^{\prime}$-NTR) and P1 sequences was cloned with the 5'RACE (rapid amplification of cDNA ends) system (version 2.0, Gibco BRL) according to the manufacturer's instructions. cDNA synthesis was carried out on 500 ng of viral RNA with PVV-specific primer 5 (Table 2). Subsequent PCR amplification was carried out with primer 7 (Table 2), and primer 5'AAP (5'RACE-abridged anchor primer). Two independently amplified PCR products were cloned and sequenced. The first nucleotide of the genomic RNA in PVV Dv42 was confirmed by the primer extension technique as previously described (51). Viral RNA (500 ng) was denatured at $80^{\circ} \mathrm{C}$ for $10 \mathrm{~min}$ and cooled to $50^{\circ} \mathrm{C}$ to allow primer 12 to anneal (Table 2). cDNA synthesis was carried out at $50^{\circ} \mathrm{C}$ for $50 \mathrm{~min}$ with Superscript II reverse transcriptase (Gibco BRL).

The $5^{\prime}$ - and $3^{\prime}$-terminal sequences were determined in the other six PVV isolates. The 5'-NTR and P1-encoding regions were amplified and cloned with primers 7 and 13 (Table 2), whereas the CPencoding and 3'-NTR regions (except for PVV Dv42) were amplified and cloned with primers 10 and 11 (Table 2). Sequencing was done on both strands from at least two independently PCR-amplified clones.

Secondary structures of $\mathbf{3}^{\prime}$-NTR. Secondary structures were analyzed in the $3^{\prime}$-NTR (excluding the poly(A) tail) region by the

TABLE 3. Viral sequences and their EMBL databank accession numbers

\begin{tabular}{ll}
\hline Virus & Accession number (genomic region) ${ }^{\mathrm{a}}$ \\
\hline $\begin{array}{l}\text { Potato virus } V^{\mathrm{b}} \\
\text { Dv42 }\end{array}$ & \\
502 & AJ243766 (complete genomic sequence) \\
& AJ243760 (5'-NTR and P1) \\
& AJ253119 (CP) \\
506 & AJ253113 (3'-NTR) \\
& AJ243761 (5'-NTR and P1) \\
& AJ253120 (CP) \\
& AJ253114 (3'-NTR) \\
508 & AJ243762 (5'-NTR and P1) \\
& AJ253121 (CP) \\
& AJ253115 (3'-NTR) \\
M95 & AJ243763 (5'-NTR and P1) \\
& AJ253122 (CP) \\
& AJ253116 (3'-NTR) \\
M97 & AJ243764 (5'-NTR and P1) \\
& AJ253123 (CP) \\
& AJ253117 (3'-NTR) \\
Ringeriks & AJ243765 (5'-NTR and P1) \\
& AJ253124 (CP) \\
& AJ253118 (3'-NTR) \\
& X61279 (5'-terminal 2,500 nt, including CP \\
& and 3'-NTR) \\
&
\end{tabular}

Potato virus $Y^{\mathrm{c}}$

PVY ${ }^{\mathrm{N}}-\mathrm{N}$

PVYNTN-H

PVYO-139

PVYC-27

$\mathrm{PVY}^{\mathrm{C}}-28$

$\mathrm{PVY}^{\mathrm{C}}-30$

$\mathrm{PVY}^{\mathrm{C}}-45$

PVY1-P21

PVY1-Chil

PVY ${ }^{1}$-Eur-H

$\mathrm{PVY}^{1}-\mathrm{NsNr}$

$\mathrm{PVY}^{1}-\mathrm{MsNr}$

PVY1-US

D00441 (complete genomic sequence) M95491 (complete genomic sequence) U09509 (complete genomic sequence) AF012026 (CP)

$\mathrm{AF} 012027$ (CP)

$\mathrm{AF} 012028$ (CP)

AF012029 (CP)

AJ005639 (CP)

X68221 (CP)

$\mathrm{X} 68223(\mathrm{CP})$

$\mathrm{X} 68224$ (CP)

$\mathrm{X} 68225(\mathrm{CP})$

$\mathrm{X} 68222$ (CP)

Potato virus A

PVA-Ali

PVA-B11

PVA-Her

PVA-TamMV

PVA-U

PVA-716/12

PVA-Adv

PVA-Dat

PVA-Jul

PVA-M

PVA-Sro

AJ131401 (complete genomic sequence) Z21670 (complete genomic sequence) AJ131400 (complete genomic sequence)

AJ131403 (complete genomic sequence)

AJ131402 (complete genomic sequence)

Y11427 (CP)

Y10250 (CP)

$\mathrm{Y} 11426(\mathrm{CP})$

X91968 (CP)

Z49088 (CP)

Pepper mottle virus PepMoV-C

PepMoV

Plum pox virus

PPV-NAT

PPV-D

X91967 (CP)

M96425 (complete genomic sequence) M11598 (CP)

D13751 (complete genomic sequence)

X16415 (complete genomic sequence)

Tobacco etch virus TEV-HAT

M11458 (complete genomic sequence)

Tobacco vein mottling virus TVMV

X04083 (complete genomic sequence)

Pea seedborne mosaic virus PSbMV-DPD1

D10930 (complete genomic sequence)

a 5'-NTR and 3'-NTR, 5'-terminal and 3'-terminal nontranslated regions, respectively; P1, region encoding first protein; CP, coat protein-encoding region.

b Sequences of all isolates except 'Irish' were determined in this study.

c Potato virus $Y$ isolates from potato belonging to strains $\mathrm{O}\left(\mathrm{PVY}^{\mathrm{O}}\right), \mathrm{N}\left(\mathrm{PVY}^{\mathrm{N}}\right)$, and $\mathrm{C}(\mathrm{PVY})$, as well as isolates $\left(\mathrm{PVY}^{1}\right)$ from pepper and tobacco, were included. 
MFOLD program (64) (available on-line from the Institut Pasteur, Paris).

Phylogenetic analyses. The Wisconsin package (version 8, Genetics Computer Group, Madison, WI) (16) was used to analyze the sequences of PVV and other potyviruses. The sequences and their accession numbers are listed in Table 3. The multiple alignments of the nucleotide sequences and the deduced amino acid sequences were built with the PILEUP program (24) and used to calculate the percentages of nucleotide sequence identity and amino acid sequence similarity with the DISTANCES program (Genetics Computer Group).

Phylogenetic relationships were analyzed with PHYLIP (18). Genetic distances were determined, and unrooted phylogenetic trees were generated using the $\mathrm{CI}$ and $\mathrm{CP}$ sequences. Distance matrices were calculated from the aligned sequences using the PROTDIST program and Dayhoff PAM matrix (amino acid sequences) (13) or the DNADIST and DNAPARS programs and Kimura two-parameter model (nucleotide sequences) (34). Phylogenies were inferred using the generated matrices as an input in the NEIGHBOR program, which uses the neighbor-joining method (50). One hundred bootstrapped data sets were generated using SEQBOOT to estimate the statistical significance of branching. The consensus tree was built using the CONSENSE and TREEVIEW programs.

\section{RESULTS}

Genome structure of PVV. The genome length of isolate PVV Dv42 is $9,851 \mathrm{nt}$, followed by a poly(A) tail. The sequence has been deposited in the EMBL databank (Accession no. AJ243766) and is not shown here.

Computer analysis of the sequence revealed a single open reading frame (ORF) starting at nucleotide 205 and ending with a UAG stop codon at nucleotide 9406 . Thus, the lengths of the $5^{\prime}$ - and $3^{\prime}-$ NTRs were 204 and $446 \mathrm{nt}$, respectively. The NTR regions were rich in adenine and uracil (5'-NTR: 68.1\%; 3'-NTR: 62.3\%), in

\begin{tabular}{|c|c|c|c|c|c|c|c|c|}
\hline 5'-NTR P1 & HC-Pro & P3 $6 \mathrm{~K}$ I & CI & $6 \mathrm{~K} 2 \mathrm{~V}$ & -NIa & NIb & CP & $3^{\prime}$-NTR \\
\hline 32 & 52 & 41 & 71 & 21 & 28 & 59 & 30 & _Poly $(\mathrm{A})$ \\
\hline & & $\overline{8}$ & & 䒺帝 & & & & $\stackrel{\omega}{\circ}$ \\
\hline
\end{tabular}

Fig. 1. Genomic organization of the Potato virus $V$ genome (isolate Dv42). The number of the last amino acid residue of each protein-encoding region in the polyprotein is indicated, and calculated molecular weights (kilodaltons) are indicated for each protein. 5'-NTR and 3'-NTR, 5'- and $3^{\prime}$-terminal nontranslated regions, respectively; P1, proteinase; HC-Pro, helper componentproteinase; $\mathrm{P} 3$, third protein; $6 \mathrm{~K} 1,6-\mathrm{kDa}$ protein 1 ; $\mathrm{CI}$, helicase; $6 \mathrm{~K} 2,6-\mathrm{kDa}$ protein 2; VPg, viral genome-linked protein; NIa, proteinase; NIb, replicase; $\mathrm{CP}$, coat protein $(45)$ contrast to the remainder of the PVV sequence (56\%). The first $35 \mathrm{nt}$ of the $5^{\prime}$-NTR are highly conserved among the previously characterized potyviruses (illustrated in Simón-Buela et al. [53]), which was also the case for PVV, including "box a" at nucleotides 10-21 and "box b" at nucleotides 32-39 (33,52). The PVV 5'-NTR contained many CAA nucleotide motifs described for the $\Omega^{\prime}$ sequence of Tobacco mosaic virus (genus Tobamovirus) associated with translation enhancement (22), which has led to the view that the CAA motifs of the potyviral $5^{\prime}$-NTR also mediate the translation enhancement shown for the potyviral $5^{\prime}$-NTR $(11,41)$.

The 3'-NTR sequence in potyviruses is involved in the initiation of minus-strand RNA synthesis (9) and can affect the severity of virus-induced symptoms (47). Computer analysis predicted that the exceptionally long 3'-NTR sequence of PVV is folded into stable secondary structures $(-502 \mathrm{~kJ})$ (data not shown), in contrast to the 5 -NTR. Comparison of the predicted secondary structure of PVV $3^{\prime}$-NTR with the $3^{\prime}$-NTR in PVY ${ }^{\mathrm{N}}$-N $(331 \mathrm{nt},-360 \mathrm{~kJ})$, PepMoVC (269 nt, $-293 \mathrm{~kJ})$, and PVA-U (207 nt, $-184 \mathrm{~kJ})$ failed to reveal a common structure, as was previously suggested for different potyviruses (54).

The single ORF of PVV encodes a putative polyprotein of 3,067-aa residues $\left(M_{\mathrm{r}} 346 \mathrm{kDa}\right)$ (Fig. 1). Nine putative protease cleavage sites were identified compared with the consensus protease recognition motifs in potyviruses (45). No novel cleavage site was found. Hence, the PVV polyprotein is likely to be processed into 10 smaller proteins (Fig. 1) by the 3 viral-encoded proteases: P1, HC-Pro, and NIa (45). The putative cleavage sites for PVV NIa and HC-Pro proteases were identical to those in PepMoV (60) and PVY (46), whereas the putative cleavage site for P1 more closely resembled that of PVY (46).

The previously identified and highly conserved amino acid sequence motifs of potyviruses (52) also were present at analogous positions in the PVV proteins. For example, the proteolytic domain FxxRG and the serine-type protease domain $\left(\mathrm{Hx}_{8} \mathrm{Dx}_{31} \mathrm{GxSG}\right)(63)$ were found in P1. The CCC, PTK, and LAIGN motifs of HC-Pro involved in viral long-distance movement (12), aphid transmission (26), and cell-to-cell movement (12), respectively, also were found in the PVV HC-Pro protease. However, the KITC amino acid motif of HC-Pro involved in transmissibility by aphids (3) was found in the form of KLTC in PVV, similar to PepMoV. The KLTC motif was functional for aphid transmissibility, because PVV isolate Dv42 was transmitted by $M$. persicae (data not shown). The conserved nucleotide-binding motif of the CI helicase and the conserved motifs shared by all RNA-dependent RNA polymerases (NIb in PVV) of the positive-strand RNA viruses (35) also were found in PVV. The DAG tripeptide required for aphid transmission $(2,4)$ was present at the $\mathrm{N}$ terminus of the $\mathrm{CP}$.

TABLE 4. Pairwise comparison of the percent nucleotide sequence identities and the percent of amino acid sequence similarities in genomic regions between Potato virus V (PVV) isolate Dv42 and Pepper mottle virus (PepMoV), Potato virus Y (PVY), and Potato virus A (PVA)

\begin{tabular}{|c|c|c|c|c|c|c|c|c|c|c|c|c|}
\hline $\begin{array}{l}\text { Virus } \\
\text { Sequence }\end{array}$ & $5^{\prime}$-NTR & P1 & $\mathrm{HC}$ & P3 & $6 \mathrm{~K} 1$ & CI & $6 \mathrm{~K} 2$ & VPg & NIaPro & $\mathrm{NIb}$ & $\mathrm{CP}$ & 3'-NTR \\
\hline \multicolumn{13}{|l|}{ PepMoV-C } \\
\hline Nucleotide & 51.7 & 48.1 & 54.8 & 44.3 & 57.7 & 64.9 & 65.6 & 66.0 & 61.5 & 64.2 & 67.5 & 52.8 \\
\hline \multicolumn{13}{|l|}{$\mathrm{PVY}^{\mathrm{O}}-139$} \\
\hline Nucleotide & 53.2 & 53.6 & 53.1 & 39.4 & 55.8 & 58.6 & 57.3 & 63.7 & 53.7 & 61.8 & 65.4 & \\
\hline $\begin{array}{l}\text { Amino acid } \\
\text { PVYNTN }_{-H}\end{array}$ & & 37.3 & 54.4 & 35.8 & 59.6 & 70.3 & 44.2 & 72.3 & 61.1 & 72.6 & 65.2 & 43.0 \\
\hline $\mathrm{PVY}^{\mathrm{NTN}}-\mathrm{H}$ & & & & & & & & & & & & \\
\hline \multicolumn{13}{|l|}{$\mathrm{PVY}^{\mathrm{N}}-\mathrm{N}$} \\
\hline Nucleotide & 55.2 & 54.7 & 53.9 & 38.8 & 57.1 & 59.0 & 65.6 & 61.5 & 54.5 & 61.4 & 64.9 & 42.2 \\
\hline Amino acid & & 38.0 & 54.4 & 33.5 & 59.6 & 70.2 & 48.1 & 70.7 & 60.7 & 70.3 & 65.2 & \\
\hline \multicolumn{13}{|l|}{ PVA-U } \\
\hline Nucleotide & 37.9 & 24.0 & 45.2 & 28.5 & 42.3 & 48.1 & 39.1 & 47.7 & 46.6 & 54.1 & 52.7 & 26.8 \\
\hline Amino acid & & 21.8 & 44.4 & 22.8 & 44.2 & 51.4 & 42.3 & 43.6 & 48.6 & 58.1 & 52.8 & \\
\hline
\end{tabular}

a 5'-and 3'-NTR, 5'-terminal and 3'-terminal nontranslated regions, respectively; P1, region encoding first protein; HC, helper component-proteinase; P3, third protein; 6K1, 6-kDa protein 1; CI, helicase; 6K2, 6-kDa protein 2; VPg, viral genome-linked protein; NIaPro, proteinase; NIb, replicase; CP, coat protein-encoding region. 
Genetic relationship of PVV to other potyviruses. The highest overall amino acid sequence similarity was found between the polyprotein of PVV (3,067 aa) and PepMoV-C (3,068 aa; 64.2\%) and the different PVY isolates $(3,061$ to 3,063 aa; $\approx 58 \%)$. The overall similarity to other potyviruses was less than $50 \%$ (including PVA with 3,059 aa; $\approx 44 \%$ ).

The amino acid similarities and shared nucleotide identities between PVV, PVA, PepMoV, and PVY are shown in Table 4. The NTRs, P1, P3, and CP were the most variable regions, whereas the $\mathrm{CI}, \mathrm{VPg}$, and NIb were the most conserved regions among these potyviruses (Table 4). In P1 and $\mathrm{CP}$, most of the variable amino acid residues were located at the $\mathrm{N}$ terminal part of the protein.

The taxonomic position of PVV among the potyviruses naturally infecting solanaceous species (using the viruses from which the complete genomic sequence was available) was determined based on the genetic distances estimated from the nucleotide and amino acid sequence alignments of the CI region, as recommended by Lee et al. (36). The CI is used because it is the largest proteinencoding region in potyviruses and one of the regions showing the least intraspecific variability $(36,52)$. The results indicated the closest relationship was between PVV and PepMoV (Fig. 2). A phylogenetic analysis with the $\mathrm{CP}$ sequences provided a similar result (data not shown), which is consistent with a previous report (6).

Genetic variability of PVV. Serological tests and host plant responses were used to establish that all virus isolates were PVV. All isolates were detected with the MAb and PAb to PVV, whereas none of them was detected with the PAbs to PVY or PAbs and MAbs to PVA (Table 5). On the other hand, the antibodies to PVV did not detect the isolates of PVY, PVA, and PepMoV tested.

Four indicator hosts were selected for their proven ability to distinguish different potato-infecting potyvirus species (PVY, PVA, and PVV) and to distinguish between most strains of PVY and PVA $(7,14,15,21,29,44,57-59)$. The observed host responses clearly differentiated PVV from PVY, PVA, and PepMoV (Table 5), which was consistent with previous studies on indicator hosts $(21,29,55)$. The only difference from previous studies was that the A6 plants developed mosaic symptoms, and no necrosis was observed after infection with PVV, whereas Fribourg and Nakashima (21) observed limited vein necrosis on the under side of leaves. The dif- ference could be due to different experimental conditions (e.g., temperature and light) in the two studies. The symptoms induced in indicator hosts were similar for all the PVV isolates tested, suggesting limited variability among isolates. In contrast, the strains of PVY and PVA were distinguished by the four indicator hosts (Table 5).

$\mathrm{PVY}^{\mathrm{C}}$ was not included in the experiments, but it is known to induce mosaic symptoms in tobacco cultivars that react with vein necrosis symptoms to $\mathrm{PVY}^{\mathrm{N}}(15)$. Furthermore, potato cv. Pentland Crown is susceptible to $\mathrm{PVY}^{\mathrm{C}}$ and produces mosaic symptoms, whereas it has an HR reaction to $\mathrm{PVY}^{\mathrm{O}}(29)$. Within $\mathrm{PVY}^{\mathrm{C}}$, isolates are indistinguishable serologically and in host responses, but

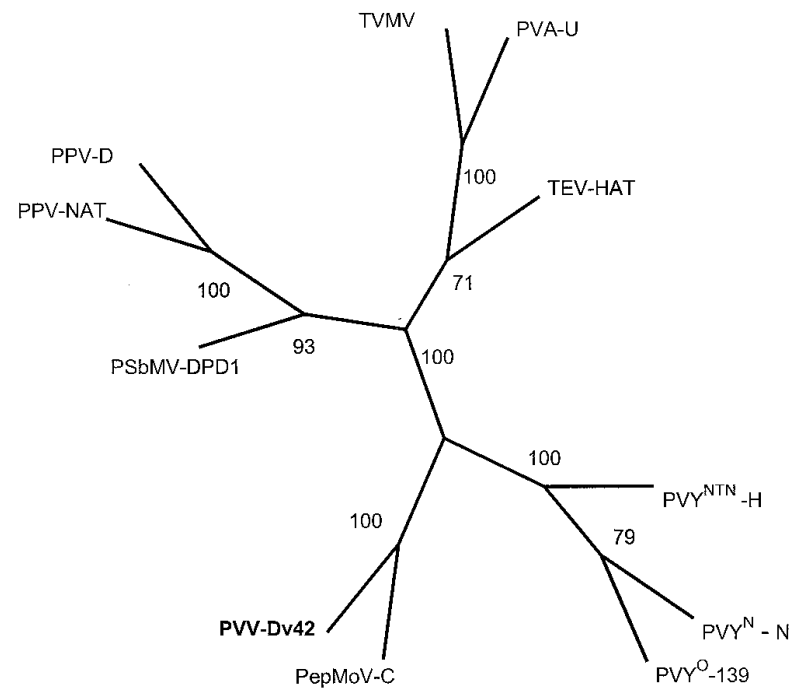

Fig. 2. Bootstrapped phylogenetic tree based on genetic distances calculated using the cylindrical inclusion (CI) protein amino acid sequences of selected potyvirus species infecting Solanaceae. Pea seed-borne mosaic virus (PSbMV) is uncommon in solanaceous species and was used as an outgroup. PPV, Plum pox virus; TVMV, Tobacco vein mottling virus; TEV, Tobacco etch virus; PVV, Potato virus V; PVY, Potato virus Y; PepMoV, Pepper mottle virus.

TABLE 5. Some serological and biological properties of the Potato virus V(PVV) isolates included in this study

\begin{tabular}{|c|c|c|c|c|c|c|c|c|c|}
\hline \multirow[b]{3}{*}{ Isolate } & \multicolumn{5}{|c|}{ Detection with antibodies to ${ }^{a}$} & & & & \\
\hline & \multicolumn{2}{|c|}{ PVV } & \multirow[b]{2}{*}{ PVY PAb } & \multicolumn{2}{|c|}{ PVA } & \multicolumn{4}{|c|}{ Symptoms ${ }^{b}$} \\
\hline & MAb 53/8 & $\mathrm{PAb}$ & & MAb 58/0 & MAb 58/6 & A6 & Samsun nn & Pentland Crown & RNaky \\
\hline \multicolumn{10}{|l|}{ PVV } \\
\hline DV42 & +++ & +++ & - & - & - & SM & $\mathrm{MVCl}$ & $\mathrm{Y}, \mathrm{VN}$ & NI \\
\hline M95 & +++ & +++ & - & - & - & SM & $\mathrm{MVCl}$ & Y,VN & NI \\
\hline M97 & +++ & +++ & - & - & - & SM & $\mathrm{MVCl}$ & Y,VN & NI \\
\hline 502 & +++ & +++ & - & - & - & SM & $\mathrm{MVCl}$ & $\mathrm{Y}, \mathrm{VN}$ & NI \\
\hline 506 & +++ & +++ & - & - & - & SM & $\mathrm{MVCl}$ & Y,VN & NI \\
\hline 508 & +++ & +++ & - & - & - & SM & $\mathrm{MVCl}$ & $\mathrm{Y}, \mathrm{VN}$ & NI \\
\hline Ringeriks & +++ & +++ & - & - & - & SM & $\mathrm{MVCl}$ & $\mathrm{Y}, \mathrm{VN}$ & NI \\
\hline \multicolumn{10}{|l|}{ Control } \\
\hline PVYO-UK & - & - & +++ & - & - & NLL & $\mathrm{M}$ & VN & $\mathrm{M}$ \\
\hline PVYN-RUS & - & - & ++ & - & - & $\mathrm{M}$ & VN & SS & NI \\
\hline PVA-U & - & - & - & +++ & +++ & NLL & $\mathrm{MVCl}$ & SS & NI \\
\hline PVA-B11 & - & - & - & +++ & - & NLL & $\mathrm{VCl}$ & NSI & $\mathrm{nt}$ \\
\hline PVA-TamMV & - & - & - & +++ & +++ & NLL & $\mathrm{VCl}$ & NSI & nt \\
\hline Pepper mottle virus & - & - & - & - & - & NI & $\mathrm{VCl}, \mathrm{M}$ & NI & M \\
\hline
\end{tabular}

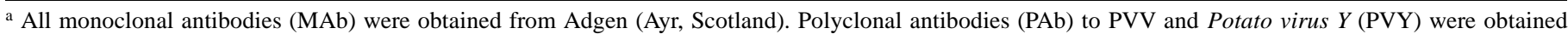
from Bioreba (Corrobora, NC) and Boehringer GmbH (Mannheim, Germany), respectively. PVA, Potato virus A. Enzyme-linked immunosorbent assay (ELISA) absorbance values from infected leaves of tobacco cv. Samsun nn after 60 min of development of color reaction:,$+++>2.50$; ++, 1.50 to 2.49 ; - , similar to healthy plants $(0.04$ to 0.09$)$.

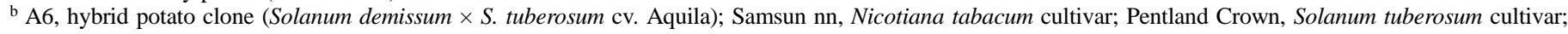
RNaky, Capsicum annuum cultivar. Symptoms in mechanically inoculated A6, tobacco, and pepper plants: NLL, necrotic lesions in inoculated leaves 6 days postinoculation (dpi); NI, no symptoms and no virus detected by ELISA in inoculated leaves and upper noninoculated leaves 21 dpi. Other symptoms refer to upper noninoculated leaves at $21 \mathrm{dpi}$, including graft-inoculated potato plants: M, mosaic; SM, severe mosaic; SS, symptomless systemic infection detected by ELISA; MVCl, mild vein clearing; Y, yellowing; VCl, vein clearing; VN, vein necrosis; NSI, no systemic infection; nt, not tested. 
they do form genetically distinct strains based on comparisons of $\mathrm{CP}$ gene sequences (7). Therefore, the genetic diversity of the PVV isolates was investigated by determining the sequences of the most variable regions in the potyviruses $\left(5^{\prime}\right.$-NTR, P1, CP, and $3^{\prime}$ NTR) $(1,33)$. Sequence comparisons showed that the four regions were equal in length in all PVV isolates studied and contained the conserved sequence motifs mentioned earlier. The nucleotide identities for the $5^{\prime}$-NTR, P1, CP, and 3'-NTR regions were 94.6 to $99.5,96.3$ to $98.8,96.4$ to 98.7 , and 96.3 to $99.6 \%$, respectively, among the PVV isolates. The amino acid similarities for the P1 and CP were 95.8 to 98.6 and 96.0 to $97.8 \%$, respectively. The variable nucleotide and amino acid positions were not concentrated in any particular part of the $\mathrm{P} 1$ and $\mathrm{CP}$ regions but were distributed equally over the entire regions. In contrast, the $5^{\prime}$-NTR sequences were identical for the nucleotides 39-61 (nucleotides 1-38, were determined only for Dv42), followed by variable nucleotide positions over the remainder of the $5^{\prime}$-NTR. Also, in the PVY and PVA isolates, the first 59 and $61 \mathrm{nt}$, respectively, are nearly identical in the $5^{\prime}$-NTR, followed by nucleotide deletions and variable nucleotide positions in the remainder of the sequence (33).

Phylogenetic analysis of the available CP sequences of eight PVV isolates indicated no systematic grouping, as shown by the low bootstrap values of 31 to 52 . In contrast, the phylogenetic analysis of the CP sequences of PVY and PVA indicated a grouping of isolates according to previously recognized strains (Fig. 3), as previously reported and illustrated $(33,44,61,62)$, except for $\mathrm{PVY}^{\mathrm{C}}$, which is not a genetically homogeneous strain (7). However, analysis of the P1 sequences indicated a grouping of PVV isolates according to geographic origin. The isolates from the Netherlands, the United Kingdom, and Norway, each formed a different branch (bootstrap values of 78 and 71 [amino acid sequence] and 90 and 73 [nucleotide sequence]). The deduced amino acid sequence contained 26 variable amino acid positions. The isolates from the Netherlands had two unique amino acid substitutions (T89A and T282A), and isolate Ringeriks from Norway had five unique amino acid substitutions (Q66L, I125T, K208R, V217M, and N233S) compared with other isolates that were identical at these amino acid positions.

\section{DISCUSSION}

Determination of the complete genomic sequence of PVV in this study showed that it is a distinct but genetically typical member of the genus Potyvirus (52). PVV is known to occur only in the Andean Region of South America and in western Europe (27). Cultivated potato is the only known natural host of PVV, and in Europe, only a few cultivars have been infected in the field. Its

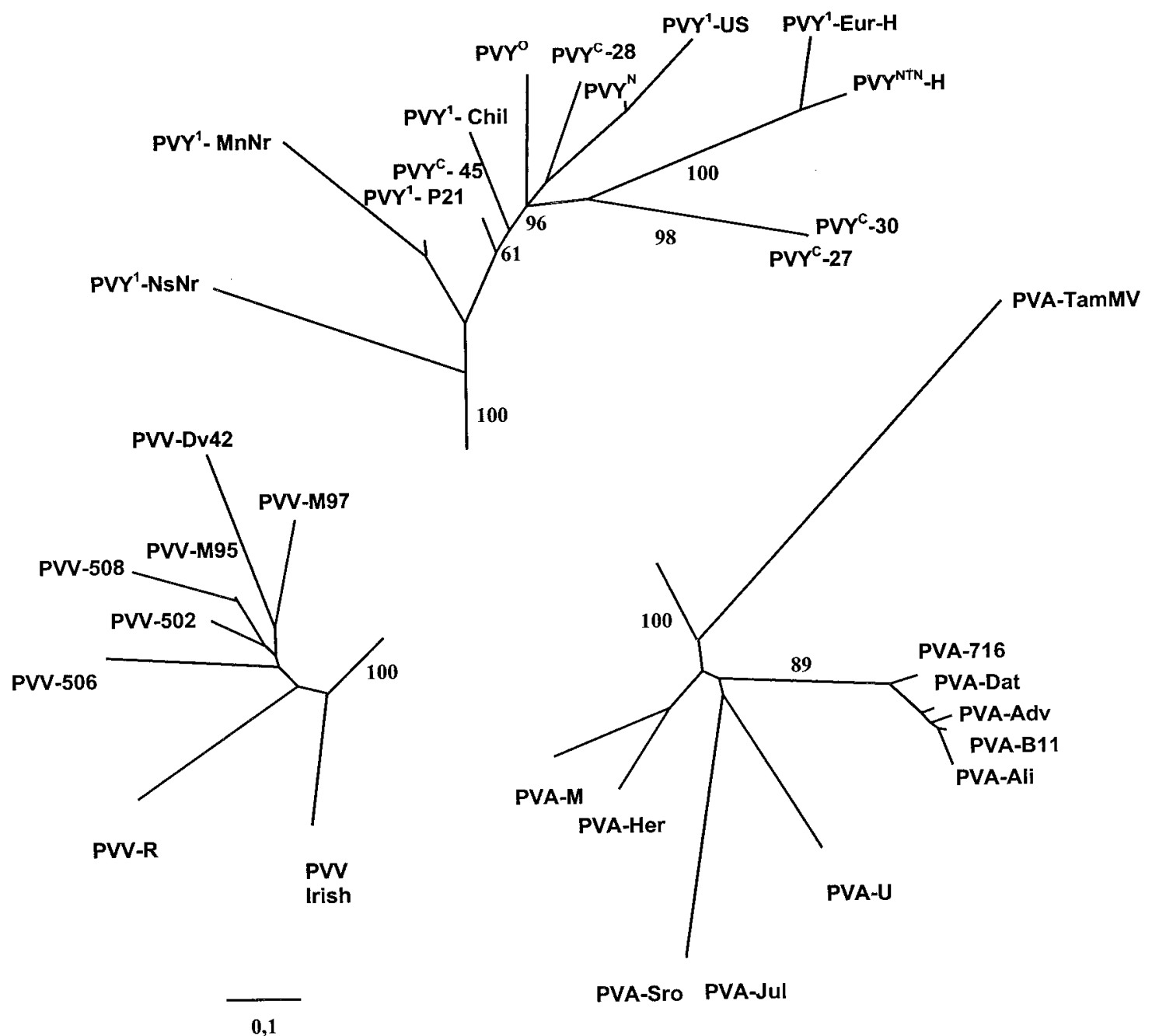

Fig 3. Phylogenetic tree based on genetic distances calculated from the coat protein (CP) amino acid sequences of all available isolates of Potato virus V (PVV) and selected isolates of Potato virus $Y$ and $A$ (PVY and PVA, respectively) (Table 3). All isolates were included in the same phylogenetic analysis, and the genetic distances between them are comparable in all clusters. However, only the clusters of sequences formed by each virus species are shown; the entire branches of the phylogenetic tree connecting virus-specific clusters are not shown because their lengths are very long compared with the branches of the virus-specific clusters. In the PVV cluster, branching pattern is not well supported, whereas in the PVA cluster the tamarillo (TamMV) and tobacco strains (isolates 716, Dat, Adv, B11, and Ali) form their own branches, which differ from the remaining strains from potato $(33,44)$. Only a few isolates of PVY from different strains and hosts (Table 3) are included; comprehensive presentations of phylogenetic analyses of PVY CP sequences are provided elsewhere (7,60,61). Bootstrap values exceeding 60 of 100 replicates are indicated. Bar $=0.1$ Dayhoff PAM matrix units. 
occurrence in only a few potato cultivars has been explained by the presence of genes for resistance (HR) to PVV in most potato cultivars $(27,28,31,55)$. No strains of PVV have been distinguished based on serological properties or responses induced in indicator hosts and potato cultivars $(21,27,28,31)$. The previous data are consistent with those from our study, which examined for the first time the genetic variability of PVV. Only limited genetic and no biological diversity was detected between the isolates collected from the Netherlands, the United Kingdom, and Norway during the past 35 years.

Although differentiation of strains among the European isolates of PVV was not supported by our analysis of the CP sequences, phylogenetic analysis of the P1 sequences suggested groupings according to country of origin. Analysis of the PVY, PVA, and Yam mosaic virus sequences have revealed that the largest amino acid sequence differences between the strains are found within the $\mathrm{P} 1$ region, and the second largest differences are found within the $\mathrm{N}$-terminal region of the $\mathrm{CP}(1,33)$. The significance of these findings is unclear. Perhaps P1 can vary relatively independently of the remainder of the polyprotein and, consequently, show the highest rate of adaptation to the host, which is considered the most significant driving force in virus evolution (48). Therefore, it is intriguing that in PVV the genetic differentiation, if any, also is detectable in the $\mathrm{P} 1$ region. This may reflect the genetic differences between the potato cultivars bred and grown in the different countries and in which the PVV isolates occur and have been maintained since the introduction of PVV into Europe.

No isolate of PVV from the Andean Region was included in our study. Examination of isolates of PVV and other potyviruses occurring in native species of Solanaceae in the Andes (the probable origin of the potyviruses infecting cultivated potatoes elsewhere in the world) will be crucial to elucidate the true intra- and interspecific variability within this group of potyviruses. For example, the molecular examination of Wild potato mosaic virus (30) and Peru tomato mosaic virus (20) might provide valuable data regarding potyvirus evolution. The limited variability of PVV reported in our study might simply reflect a biased sampling from only cultivated potatoes. Indeed, distinct strains of PVY and PVA have been isolated from different natural host species $(9,23,33,38,44)$.

\section{ACKNOWLEDGMENTS}

Financial support from the Forestry and Agricultural Research Council (SJFR Grant 32.0667/97) is gratefully acknowledged. We thank I. Browning, J. F. J. M. van den Heuvel, G. Clover and T. Munthe for providing PVV isolates; B.-L. Lennefors for the aphids; R. F. Karyeija for carrying out the aphid-transmission tests; and R. Grube and M. Kyle for the isolate of PepMoV, antibodies, and pepper seeds.

\section{LITERATURE CITED}

1. Aleman-Verdaguer, M.-E., Goudou-Urbino, C., Dubern, J., Beachy, R. N., and Fauquet, C. 1997. Analysis of the sequence diversity of the P1, HC, $\mathrm{P} 3$, NIb and $\mathrm{CP}$ genomic regions of several yam mosaic potyvirus isolates: Implications for the intraspecies molecular diversity of potyviruses. J. Gen. Virol. 78:1253-1264.

2. Andrejeva, J., Puurand, Ü., Merits, A., Rabenstein, F., Järvekülg, L., and Valkonen, J. P. T. 1999. Potyvirus helper component-proteinase and coat protein $(\mathrm{CP})$ have coordinated functions in virus-host interactions and the same CP motif affects virus transmission and accumulation. J. Gen. Virol. 80:1133-1139.

3. Atreya, C. D., and Pirone, T. P. 1993. Mutational analysis of the helper component-proteinase gene of a potyvirus: Effects of amino acid substitutions, deletions, and gene replacement on virulence and aphid transmissibility. Proc. Natl. Acad. Sci. USA 90:11919-11923.

4. Atreya, P. L., López-Moya, J. J., Chu, M., Atreya, C. D., and Pirone, T. P. 1995. Mutational analysis of the coat protein N-terminal amino acids involved in potyvirus transmission by aphids. J. Gen. Virol. 76:265-270.

5. Bartels, R. 1971. Potato virus A. No. 54 in: Descriptions of Plant Viruses. Commonw. Mycol. Inst./Assoc. Appl. Biol., Kew, England.

6. Berger, P. H., Wyatt, S. D., Shiel, P. J., Silbernagel, M. J., Druffel, K., and
Mink, G. I. 1997. Phylogenetic analysis of the Potyviridae with emphasis on legume-infecting potyviruses. Arch. Virol. 142:1979-1999.

7. Blanco-Urgoiti, B., Sánchez, F., Pérez de San Román, C., Dopazo, J., and Ponz, F. 1998. Potato virus Y group C isolates are homogeneous pathotype but two different genetic strains. J. Gen. Virol. 79:2037-2042.

8. Browning, I. A., Burns, R., George, E. L., and Darling, M. 1995. Development and evaluation of ELISA assays incorporating monoclonal antibodies for the detection of potato A potyvirus. EPPO Bull. 25:259-268.

9. Bryan, G. T., Gardner, R. C., and Foster, R. L. S. 1992. Nucleotide sequence of the coat protein gene of a strain of clover yellow vein virus from New Zealand: Conservation of a stem-loop structure in the $3^{\prime}$ region of potyviruses. Arch. Virol. 124:133-146.

10. Calvert, E. L., Cooper, P., and McClure, J. 1980. An aphid-transmitted strain of PVYC recorded in potatoes in Northern Ireland. Rec. Agric. Res. Dep. Agric. N. Ireland 28:63-74.

11. Carrington, J. C., and Freed, D. D. 1990. Cap-independent enhancement of translation by a plant potyvirus $5^{\prime}$ nontranslated region. J. Virol. 64: 1590-1597.

12. Cronin, S., Verchot, J., Haldeman-Cahill, R., Schaad, M. C., and Carrington, J. C. 1995. Long-distance movement factor: A transport function of the potyvirus helper component proteinase. Plant Cell 7:549-559.

13. Dayhoff, M. O., Schwartz, R. M., and Orcutt, B. C. 1978. A model for evolutionary change in proteins. Pages 353-358 in: Atlas of Protein Sequence and Structure. Vol. 3, Suppl. 3. National Biochemistry Research Foundation, Washington DC.

14. De Bokx, J. A. 1972. Test plants. Pages 102-110 in: Viruses of Potatoes and Seed-Potato Production. Pudoc Scientific Publishers, Wageningen, Netherlands.

15. De Bokx, J. A., and Huttinga, H. 1981. Potato virus Y. No. 242 in: Descriptions of Plant Viruses. Commonw. Mycol. Inst./Assoc. Appl. Biol., Kew, England.

16. Deveneux, J., Maerberli, P., and Smithies, O. 1984. A comprehensive set of sequence analysis programs for the VAX. Nucleic Acids Res. 12:387395.

17. Fauquet, M. C., and Mayo, M. A. 1999. Abbreviations for plant virus names-1999. Arch. Virol. 144:1249-1273.

18. Felsenstein, J. 1993. PHYLIP (Phylogeny Inference Package). Version 3.57c. Department of Genetics, University of Washington, Seattle.

19. Fisher, M. L. 1995. The genetics and evolution of potyvirus-host gene interactions in Phaseolus vulgaris L. Ph.D. thesis. Department of Plant Breeding and Biometry, Cornell University, Ithaca, NY.

20. Fribourg, C. E. 1979. Host plant reactions, some properties, and serology of Peru tomato virus. Phytopathology 69:441-445.

21. Fribourg, C. E., and Nakashima, J. 1984. Characterization of a new potyvirus from potato. Phytopathology 74:1363-1369.

22. Gallie, D. R., and Walbot, V. 1992. Identification of the motifs within the tobacco mosaic virus $5^{\prime}$ leader responsible for enhancing translation. Nucleic Acids Res. 20:4631-4638.

23. Gébré Sélassié, K., Marchoux, G., Delecolle, B., and Pochard, E. 1985. Variabilité naturelle des souches du virus Y de la pomme de terre dans les cultures de piment du sud-est de la France: Caractérisation et classification en pathotypes. Agronomie 5:621-630.

24. Gish, W. G., and States, D. J. 1993. Identification of protein coding regions by database similarity search. Nat. Genet. 3:266-272.

25. Hooker, W. J. 1981. Compendium of Potato Diseases. The American Phytopathological Society, St. Paul, MN.

26. Huet, H., Gal-On, A., Meir, E., Lecoq, H., and Raccah, B. 1994. Mutations in the helper component protease gene of zucchini yellow mosaic virus affect its ability to mediate aphid transmissibility. J. Gen. Virol. 75:1407-1414.

27. Jeffries, C. J. 1998. Potato. No. 19. in: FAO/IPGRI Technical Guidelines for the Safe Movement of Germplasm. Food Agricultural Organization and International Plant Genetics Institute, Rome.

28. Jones, R. A. C. 1987. Problems associated with potyviruses in potato certification-Field inspection and serological testing. EPPO Bull. 17:6167.

29. Jones, R. A. C. 1990. Strain group specific and virus specific hypersensitive reactions to infection with potyviruses in potato cultivars. Ann. Appl. Biol. 117:93-115.

30. Jones, R. A. C., and Fribourg, C. E. 1979. Host plant reactions, some properties, and serology of wild potato mosaic virus. Phytopathology 69:446-449.

31. Jones, R. A. C., and Fribourg, C. E. 1986. Potato virus V. No. 316 in: Descriptions of Plant Viruses. Commonw. Mycol. Inst./Assoc. Appl. Biol., Kew, England.

32. Jones, R. A. C., and Fuller, N. J. 1984. Incidence of potato virus V in potato stocks in England and Wales. Plant Pathol. 33:595-597.

33. Kekarainen, T., Merits, A., Oruetxebarria, I., Rajamäki, M.-L., and Valkonen, J. P. T. 1999. Comparison of the complete sequences of five different 
isolates of Potato virus A (PVA), genus Potyvirus. Arch. Virol. 144:23552366.

34. Kimura, M. 1980. A simple method for estimating evolutionary rates of base substitutions through comparative studies of nucleotide sequences. J. Mol. Evol. 16:111-120.

35. Koonin, E. V., and Dolja, V. V. 1993. Evolution and taxonomy of positive-strand RNA viruses: Implications of comparative analysis of amino acid sequences. Crit. Rev. Biochem. Mol. Biol. 28:375-430.

36. Lee, K.-C., Mahtani, P. H., Chng, C.-G., and Wong, S.-M. 1997. Sequence and phylogenetic analysis of the cytoplasmic inclusion protein gene of zucchini yellow mosaic potyvirus: Its role in classification of the Potyviridae. Virus Genes 14:41-53.

37. Le Romancer, M., and Kerlan, C. 1991. La maladie des nécroses annulaires superficielles des tubercules: Une affection de la pomme de terre, due au virus Y. Agronomie 11:889-900.

38. Marte, M., Bellezza, G., and Polverari, A. 1991. Infective behaviour and aphid-transmissibility of Italian isolates of potato virus $\mathrm{Y}$ in tobacco and peppers. Ann. Appl. Biol. 118:309-317.

39. Matthews, R. E. F. 1991. Criteria for the recognition of strains. Pages 482503 in: Plant Virology. 3rd ed. Academic Press, San Diego, CA.

40. Mayo, M. A., and Pringle, C. R. 1998. Virus taxonomy-1997. J. Gen. Virol. 79:649-657.

41. Nicolaisen, M., Johansen, E., Poulsen, G. B., and Bokhardt, B. 1992. The $5^{\prime}$ untranslated region from pea seed-borne mosaic potyvirus RNA as a translational enhancer in pea and tobacco protoplasts. FEBS Lett. 303: 169-172.

42. Purcifull, D. E., Zitter, T. A., and Hiebert, E. 1975. Morphology, host range, and serological relationships of pepper mottle virus. Phytopathology 65: 559-562.

43. Puurand, Ü., Mäkinen, K., Paulin, L., and Saarma, M. 1994. The nucleotide sequence of potato virus A genomic RNA and its sequence similarities with other potyviruses. J. Gen. Virol. 75:457-461.

44. Rajamäki, M., Merits, A., Rabenstein, F., Andrejeva, J., Paulin, L., Kekarainen, T., Kreuze, J. F., Forster, R. L. S., and Valkonen, J. P. T. 1998. Biological, serological and molecular differences among isolates of potato A potyvirus. Phytopathology 88:311-321.

45. Riechmann, J. L., Laín, S., and García, J. A. 1992. Highlights and prospects of potyvirus molecular biology. J. Gen. Virol. 73:1-16.

46. Robaglia, C., Durand-Tardif, M., Tronchet, M., Boudazin, G., AstierManifacier, S., and Casse-Delbart, F. 1989. Nucleotide sequence of potato virus Y (N strain) genomic RNA. J. Gen. Virol. 70:935-947.

47. Rodríguez-Cerezo, E., Klein, P. G., and Shaw, J. G. 1991. A determinant of disease symptom severity is located in the 3'-terminal noncoding region of the RNA of a plant virus. Proc. Natl. Acad. Sci. USA 88:98639867.

48. Roossinck, M. J. 1997. Mechanisms of plant virus evolution. Annu. Rev. Phytopathol. 35:191-209.

49. Rozendaal, A., Van Binsbergen, J., Anema, B., Van Slogteren, D. H. M., and Burt, M. H. 1971. Serology of a deviating potato virus $\mathrm{Y}^{\mathrm{C}}$ strain in the potato variety Gladblaadje. (Abstr.) Potato Res. 14:241.

50. Saitou, N., and Nei, N. 1987. The neighbor-joining method: A new method for reconstructing phylogenetic trees. Mol. Biol. Evol. 4:406-425.

51. Sambrook, J., Fritsch, E. F., and Maniatis, T. 1989. Molecular Cloning: A Laboratory Manual. 2nd ed. Cold Spring Harbor Laboratory Press, Cold Spring Harbor, NY.

52. Shukla, D. D., Ward, C. W., and Brunt, A. A. 1994. The Potyviridae. CAB International, Wallingford, England.

53. Simón-Buela, L., Guo, H. S., and García, J. A. 1997. Long sequences in the $5^{\prime}$ noncoding region of plum pox virus are not necessary for viral infectivity but contribute to viral competitiveness and pathogenesis. Virology 233:157-162.

54. Turpen, T. 1989. Molecular cloning of a potato virus Y genome: Nucleotide sequence homology in non-coding regions of potyviruses. J. Gen. Virol. 70:1951-1960.

55. Valkonen, J. P. T. 1997. Novel resistances to four potyviruses in tuberbearing potato species, and temperature-sensitive expression of hypersensitive resistance to potato virus Y. Ann. Appl. Biol. 130:91-104.

56. Valkonen, J. P. T., Brigneti, G., Salazar, L. F., Pehu, E., and Gibson, R. W. 1992. Interactions of the Solanum spp. of the Etuberosa group and nine potato-infecting viruses and a viroid. Ann. Appl. Biol. 120:301-313.

57. Valkonen, J. P. T., Jones, R. A. C., Slack, S. A., and Watanabe, K. N. 1996. Resistance specificities to viruses in potato: Standardization of nomenclature. Plant Breed. 115:433-438.

58. Valkonen, J. P. T., Kyle, M. M., and Slack, S. A. 1996. Comparison of resistance to potyviruses within Solanaceae: Infection of potatoes with tobacco etch potyvirus and peppers with potato $\mathrm{A}$ and $\mathrm{Y}$ potyviruses. Ann. Appl. Biol. 129:25-38.

59. Valkonen, J. P. T., Puurand, Ü., Slack, S. A., Mäkinen, K., and Saarma, M. 1995. Three strains of potato A potyvirus based on hypersensitive responses in potato, serological properties, and coat protein sequences. Plant Dis. 79:748-753.

60. Vance, V. B., Moore, D., Turpen, T. H., Bracker, A., and Hollowell, V. C. 1992. The complete nucleotide sequence of pepper mottle virus genomic RNA: Comparison of the encoded polyprotein with those of the other sequenced potyviruses. Virology 191:19-30.

61. Van den Heuvel, J. F. J. M., Van der Vlugt, R. A. A., Verbeek, M., Haan, P. T., and Huttinga, H. 1994. Characteristics of a resistance-breaking isolate of potato virus $\mathrm{Y}$ causing potato tuber necrotic ringspot disease. Eur. J. Plant. Pathol. 100:347-356.

62. Van der Vlugt, R. A. A., Leunissen, J., and Goldbach, R. 1993. Taxonomic relationships between distinct potato virus $\mathrm{Y}$ isolates based on detailed comparison of the viral coat proteins and 3'-nontranslated regions. Arch. Virol. 131:361-375.

63. Verchot, J., Koonin, E. V., and Carrington, J. C. 1991. The 35-kDa protein from the $\mathrm{N}$ terminus of a potyviral polyprotein functions as a third virus-encoded proteinase. Virology 185:527-535.

64. Zucker, M. 1989. On finding all suboptimal foldings of an RNA molecule. Science 244:48-52. 